\title{
KinevezetTekből VAgy DELEGÁLTAKBÓL ÁLLJON A KÖZOKTATÁSI TANÁCS?
}

\author{
BAJOMI IVÁN
}

\author{
ELTE Társadalomtudományi Kar
}

Beérkezett: 2021. július 2., elfogadva: 2021. október 28.

\begin{abstract}
Az Országos Közoktatási Tanács (OKT) kezdeteivel kapcsolatos új dokumentumokat bemutató tanulmányomban először azt jelzem, hogy a dualizmus korának kezdetekor felállított testület létrejöttében fontos szerepet játszottak jóval korábbi külhoni (elsősorban porosz és francia) minták. A mintául szolgáló testületek szerveződésmódja egyes időszakokban hibrid jelleget öltött, mivel a tagokat vagy legalábbis ezek egy részét a középkori titkos királyi tanácsoktól eltérően nem felülről választották ki, hanem szerephez jutott a delegálás elve is. Egy megyei iskolatanácstól és egyes tanáregyesületektől származó javaslatok szerepet játszhattak abban, hogy az OKT szerveződésmódja is hibrid jellegü volt a megalakulása utáni években, vagyis nemcsak felülröl kiválasztott személyek, hanem delegált tagok is helyet kaphattak benne, ám utóbb az önkormányzatiság logikájával is rokonítható képviseleti elvet háttérbe szorították. Végül azt is érzékeltetem írásomban, hogy a hazai tanügyi tanácsok történetének számos későbbi fázisaiban is megfigyelhető volt a delegálás és a felülről való kinevezés elvének ütközése, illetve hibrid megoldások alkalmazása.
\end{abstract}

Kulcsszavak: Országos Közoktatási Tanács, nemzeti oktatási tanácsminták, választott vagy kinevezett tagok, az oktatási önkormányzásért fellépő szereplők, hibrid oktatási tanácsok

In my study based on new documents found in connection with the beginnings of the National Council for Public Education (OKT), I first point out that some earlier patterns (mainly Prussian and French) played an important role in the formation of the body set up in 1871, four years after the Austro-Hungarian compromise put an end to the 18-year-long military dictatorship and absolutist rule over Hungary. The way in which foreign bodies were organized took on a hybrid character in some periods, as the members, or at least some of them, were not selected from above, unlike the medieval secret royal councils, but the principle of delegation also played a role. Proposals from a county school council and some teachers' associations may have played a role in the fact that the OKT was organized in a hybrid way in the years after its formation, i.e. not only persons selected from above, but also delegated members, but later principle has

Levelező szerző: Bajomi Iván, 1141 Budapest, Szilágysomlyó utca 47/a. E-mail: bajomi.ivan@gmail.com 
been pushed into the background. Finally, I also point out in my writing that in several later phases of the history of Hungarian education councils, the conflict between the principles of delegation and top-down appointment and the application of hybrid solutions was observed.

Keywords: National Educational Council, national educational council patterns, elected or appointed members, actors for educational self-government, hybrid educational-councils

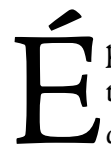

ppen másfél évszázada, 1871 decemberében fogadta el „az országos közoktatási tanács szabályzatát ő Felsége a közoktatási miniszter előterjesztésére [...]" (Az országos 1871b). A végül 1872-ben müködni kezdett testület egyike volt azoknak az új intézményeknek, amelyeknek létrehozását a politikai rendszerváltásként is értelmezhető, a korábbi, tekintélyelvű berendezkedést felváltó, viszonylag liberális dualista rendszer kialakulása tette lehetővé.

Tanulmányom egy olyan, részben az Educatio című folyóirat hasábjain közölt tanulmánysorozatba illeszkedik, amelyben azt elemeztem az elmúlt 150 év több periódusát vizsgálva, hogy az oktatást irányító minisztériumi szervek mellett milyen központi szintű tanügyi tanácsok léteztek vagy éppen „szüneteltették” müködésüket, illetve különböző szereplők milyen elképzeléseket, véleményeket fogalmaztak meg ezekkel kapcsolatban (Bajomi 2006, 2010, 2011, 2012). Kilenc évvel ezelőtt e lapban egy olyan írást publikáltam, amelyben az 1872-ben működni kezdett Országos Közoktatási Tanács (OKT) létrejöttének elözményeit, a körülötte kialakult vitákat érzékeltettem (Bajomi 2012). Munkám alapjául föként olyan sajtóközlemények szolgáltak, amelyekre az Akadémiai Könyvtárban és az Országgyülési Könyvtárban őrzött dualizmuskori lapok bekötött évfolyamait böngészve bukkantam rá. Akkori tanulmányomban több olyan, korábbi történeti munkákban nem idézett szöveget is bemutattam, amelyek azt érzékeltették, hogy az OKT 1871 decemberében királyi jóváhagyásban részesült jellemzőihez képest a korábbi viták során a politikai élet, illetve a tanügy különféle szereplői mennyire eltérő törekvéseket képviseltek. Így például egy különösen aktív egyesület, a Budai Tanáregylet 1871 nyarán egy olyan, minden bizonnyal Rill József tanítóképezdei tanár által megfogalmazott emlékiratot adott közre, amelyben egy jelentős autonómiát élvező, különféle intézmények, egyesületek képviselőiből álló testület létrehozását szorgalmazta.

Tekintettel az OKT százötven éves jubileumára, továbbá arra, hogy az Educatio folyóirat szerkesztőbizottsága, melynek magam is tagja vagyok jó ideje, ünnepi számot szentel annak, hogy harminc év óta jelennek meg folyamatosan e lap többnyire új témákat középpontba állító kötetei, úgy gondoltam, stílszerü lesz, ha úgy járulok hozzá a kettős jubileumra való emlékezéshez, ha visszatérek a tett színhelyére, azaz újra kutakodni kezdek a dualizmus idején publikált sajtótermékekben, hátha sikerül még olyan publikációkra lelnem, amelyek tovább gazdagítják az OKT kezdeteivel kapcsolatos képet. Bár annak idején felettébb szívesen jártam az Országgyưlés és az MTA patinás épületeiben működő könyvtárakba, a koronavírus-járvány harmadik hullámának lecsengése idején, 2021 júniusában úgy vehettem fel korábbi kutatásom fonalát, hogy nem kellett 
kimozdulnom otthonomból (amit persze sajnálok is), hisz a modern technika, az interneten elérhető források, különböző adatbázisok, és mindenekelőtt a hatalmas és egyre gyarapodó sajtóarchivumot rendelkezésünkre bocsátó Arcanum Digitális Tudástár dokumentumai között végezhettem eredményes kutatómunkát. Úgy gondolom, e kutakodás elősegítheti, hogy világosabb képet alkothassunk arról, hogy a bő másfél évszázaddal ezelőtti politikai rendszerváltást követően kik milyen törekvéseket képviseltek a közoktatással foglalkozó központi szintű testület létrehozásával kapcsolatban.

Noha tanulmányom végén majd kissé bővebben is megemlékezem a 150 éve létrehozott testület utóéletéről, már most jelzem, hogy e grémium kisebb megszakításokkal egészen a második világháborúig múködött, sőt e háború alatt is létezett, bár fennállása legutolsó időszakában már csak formális módon. Ez utóbbi működésmódot jól jellemezte a vele készült életútinterjúban az egykor a testület alkalmazásában állt Zibolen Endre (Sarkadi 1988: 116), kivel néhányszor beszélgethettem az Educatiót kiadó Oktatáskutatóban. Az OKT jogutódjaként hozták létre 1945-ben az Országos Köznevelési Tanácsot. Három év múltán az új diktatórikus rendszer kiépülésének egyik állomásaként „szüneteltetni” kezdték ennek a müködését, és csak a nyolcvanas évek végi politikai rendszerváltást követően vált lehetővé e tanács újjászervezése. Mindmáig létezik a szóban forgó testület, bár a politikai rendszer 2010 utáni mind diktatórikusabbá válását eredményező legutóbbi bő egy évtizedben szinte semmit sem érzékelhetünk e grémium müködéséből.

Tanulmányom első mondatában másfél évszázaddal ezelőtt létrejött intézményként beszéltem az Országos Közoktatási Tanácsról, ám ha testület megalakulásához mintaként szolgált külhoni intézmények alapításának idejét vesszük figyelembe, némi túlzással élve akár azt is mondhatjuk, hogy egy bő két évszázados múltra visszatekintő szervezetről van szó.

Horváth Mihály katolikus püspök és történész, aki nem mellesleg a Habsburgok 1849-es trónfosztását követően a vallás- és közoktatási miniszter helyetteseként müködött, majd utóbb külföldi emigrációban élt 1867-ig, hogy aztán egyéb teendői mellett 1872-től az OKT első elnökeként is tevékenykedjen, 1875-ben hosszú írást közölt (Horváth 1875) az általa elnökként irányított, alig ötéves múltra visszatekintő testületről, melyet a Pauler Tivadart a vallás- és közoktatásügyi miniszter székében felváltó Trefort Ágost minisztersége idején éppen a megszűnés veszélye fenyegetett. A tudós püspök tanulmányában részletesen foglalkozott az OKT megalakítása szempontjából különösen fontos mintaadó intézményekkel, így mindenekelőtt a Poroszországban II. Frigyes-Vilmos király idején, 1787-ben felállított Ober-Schulkollegiummal, illetve a Wilhelm Humboldt ${ }^{1}$ tudománypolitikai és oktatásirányítási szerepvállalása idején ennek helyébe lépett új testülettel, melynek számos jellemzője köszön vissza a dualizmuskori és a két világháború közötti - többször átalakított - OKT, illetve az 1945-

Wilhelm von Humboldt (1767-1835) pályája kezdetén elsősorban irodalomkritikai, filozófiai és államelméleti írásaival vált ismertté, pályája későbbi korszakában pedig kiemelkedő nyelvészeti műveket is alkotott. Többször töltött be állami hivatalt, így például évekig a Porosz Királyság római nagyköveteként tevékenykedett. 1809-től tizenhat hónapig a belügyminisztérium vallás- és közoktatásügyi osztályát vezetve vett részt a porosz állam megreformálását célzó törekvések megvalósulásában. Intézkedéseket tett az iskolarendszer egységesítése érdekében és meghatározó szerepet játszott a berlini egyetem megalapítását célzó, korábban többek között filozófusok által képviselt elképzelések tényleges megvalósításában. (Schwendtner 2017.) 
ben létrehozott, majd 1993-ban újjászervezett Országos Köznevelési Tanács (OKNT) szerveződésmódjában. Mint Horváth írta, a porosz állam kormányának 1808-as újjáalakításától fogva „a vallás és közoktatás ügyei számára a belügyminisztériumban egy külön osztály rendszereztetett. Az osztály fönökévé Humboldt Vilmos lőn kinevezve, ki aztán a kollégium helyébe a közoktatásügyi tudományos bizottságot állítá, azt tűzvén ki ennek feladatául, hogy az oktatásügy terén oly tanácsadó közegül szolgáljon, aminők a közigazgatás többi ágaiban egyéb szakértő bizottságok, például a közmunka s közegészségügyi tanácsok. E közoktatási tanács hivatása lőn a tantervek s módszerek és tankönyvek megítélése, az érettségi vizsgálatok eredményeinek fölülvizsgálása; tőle várt a kormány javaslatot és véleményt az iskola szellemi ügyeit érdeklö minden kérdésben; kötelessége volt őrködni a fölött, hogy a tudományos alapelvek a közigazgatás egyes intézkedéseire nézve irányadók legyenek; szabadságában állott ennélfogva a testületnek aggodalmait, figyelmeztetéseit, javaslatait felszólítás nélkül is a kormány elébe terjeszteni. Ezen testület volt egyszersmind a tanárvizsgáló bizottság is. Ily tudományos közoktatási tanács, a porosz tartományi állam-szervezetnek megfelelőleg három volt az országban: egy Berlinben, egy Königsbergben s egy Boroszlóban. ${ }^{2}$ Ezek 1817-ig állottak fenn, és nekik köszönhető föleg a porosz középtanodák erős, a humanisztikus irányt követő szervezete." (Horváth 1875: 458-459.)³ Egy közelmúltban megjelent publikáció fontos kiegészítésekkel szolgál a Humboldt-féle Tudományos bizottság létrejöttét és jellemzőit illetően. Schwendtner Tibor munkájából kiderül, hogy a latin eredetü, németül küldöttséget jelento” „Deputation” szó szerepelt a testület nevében (wissenschaftliche Deputation), de arra nem tér ki a szöveg, hogy pontosan miként - delegálás vagy kinevezés útján - kerültek be a testületbe a kor neves tudósai. Arra viszont egyértelmúen utal a tanulmány szerzője, hogy a Humboldt által elképzeltnél szerényebb önállóságot élvezett a grémium: „Sok vita előzte meg a Tudományos Bizottság létrehozását, Humboldt egészen magas szinten védte volna a testület zavartalan és független müködését. Például élethosszig tartó kinevezést és rendkívül magas jövedelmet akart elérni a tagok számára, akik a kor legkiválóbb tudósaiból kerülnek ki. Végül a testület 1809 decemberében alakult meg, sokkal szerényebb függetlenséggel, ám tényleg kiváló tudósok kerültek delegálásra: a filozófus Schleiermacher lett az elnöke a testületnek, a filozófus-pedagógus Herbart és a filológus Wolf pedig többek között a bizottság tagjaivá váltak (vö. Konrad 2010: 48)." (Schwendtner 2018: 71-72.) Tanulmányom elkészülte után felvettem a kapcsolatot a fenti sorok szerzőjével, akitől a következő választ kaptam a wissenschaftliche Deputation szerveződésmódjára vonatkozó kérdésemre: „Humboldt javaslata szerint (1809 december) a minisztérium, pontosabban az akkor még a Belügyminisztériumon belül müködő oktatási és vallásügyi államtitkárság és a király együttesen nevezték ki a wissenschaftliche Deputation tagjait, a tagságot évente felülvizsgálták. A király ezt a javaslatot 1810 februárjában jóváhagyta, s ezután alakult meg az első testület. Az öszszetétel praktikusan úgy alakult ki, hogy Humboldt javasolta a tagokat és a testület elnökét, s ezeket aztán a király hagyta jóvá. Humboldt nagyon gyorsan kivált a oktatási államtitkárságból, a wissenschaftliche Deputation ugyanakkor még hat évig mükö-

\footnotetext{
2 A mai Wrocłavban.

3 Tanulmányomban a dualizmus korában keletkezett szövegeket a változtatások aprólékos feltüntetésétől eltekintve kissé módosított formában közlöm. A könnyebb olvashatóság érdekében a helyesírás tekintetében a legtöbb helyen a mai szabályokat vettem figyelembe, ugyanakkor szándékosan megtartottam a kor atmoszférájának felidézését segítő régies megfogalmazásokat.
} 
dött. Ezután e testület helyett úgynevezett tudományos vizsgabizottságok alakultak." ${ }^{4}$ Schwendtner Tibor szíves közléséből kiderül, hogy a poroszországi testület tagjait nem egy vagy több szervezet delegálta, hanem egy olyan, számos komoly szellemi terméket jegyző személyiség tett javaslatot az államfőnek a Deputation összetételére, aki az idő tájt magas állami pozíciót töltött be.

Horváth Mihály 1875-ös tanulmányában a poroszországi közoktatási testületek bemutatásán túl sok teret szentelt az I. Napóleon császársága idején, 1806-ban Egyetemi Tanács néven (Conseil de l'Université) létrehozott 30 tagú grémium bemutatásának is. (Ennek neve kapcsán senki ne gondolja, hogy csupán az egyetemek müködésével foglalkozott a szóban forgó testület, hisz a Francia Egyetem [Université de France] nevet kapta a császár által végletesen egységesített oktatási rendszer, amelybe éppúgy beletartoztak a középiskolák, mint az állami egyetemek.) A pontosság kedvéért érdemes megemlíteni, hogy a Horváth Mihály által elődintézményként taglalt francia testület első változatát Közoktatási Bizottság (Conseil d’instruction publique) néven még a francia forradalom évtizedét lezáró korszak, a direktórium utolsó előtti évében, 1788-ban hozták létre. (Comité é. n.) E tanács összetételét homogénnek nevezhetjük, lévén, hogy csupán tudósokból, szám szerint nyolc személyből állt a grémium, amelynek fö feladata az volt, hogy felméréseket készítsen az oktatás helyzetéről. Az 1806-ban alapított nagyobb létszámú testület részint a tanügyigazgatási feladatokat ellátó, rektor (recteur) névvel illetett tankerületi igazgatókból, tanfelügyelőkből és iskolaigazgatókból, valamint dékánokból és egyetemi professzorokból állt. A testületi tagjainak, kiknek személyét élethossziglani időre választotta ki a napóleoni Francia Egyetem élére állított nagymester, nemcsak a tanulmányi kérdésekkel kellett foglalkozniuk különféle szekciók keretében, hanem a tanintézetek irányításával és gazdálkodásával összefüggő problémákkal, továbbá az oktatással összefüggő vitás, illetve peres ügyekkel is. (Bonaparte-Maret 1806.)

A z 1808-ban felállított francia testületnek utóbb, a különböző, egymást követő franciaországi politikai rezsimek idején több, az előbb ismertetettetekhez alapvonásaiban hasonló utódszervezete jött létre, ám a 19. század derekán egy ezektől jelentősen eltérő szerveződésmódú grémiumot hozott létre Bonaparte unokaöccse, a majdani III. Napóleon, aki akkortájt még csak köztársasági elnök volt. Az 1850 márciusában létrehozott Közoktatási Főtanács (Conseil supérieur de l’instruction publique) legfőbb új vonását az jelentette, hogy míg a korábbi testületek tudósként, egyetemi tanárként tevékenykedő tagjai fóként a tudástermelés- és tudásterjesztés szférájából rekrutálódtak, addig az 1850-ben létrehozott testületbe számos egyéb társadalmi intézmény képviselői is bekerülhettek, mégpedig delegálás útján. Különösen erős képviselethez juttatták a különféle egyházak képviselőit. Négy katolikus püspök vagy érsek, továbbá a református és az evangélikus egyház, illetve a központi izraelita konzisztórium egy-egy delegáltja vált a tanács tagjává. Ezen túlmenően a Legfőbb Semmitőszék és az Államtanács három küldötte is bekerült, akárcsak a Tudományos Akadémia (Institut) és a magániskolák három delegáltja is. Emellett létrejött egy nyolc főből álló, fizetést húzó állandó szekció, amelybe a korábbi tanácsok egyes tagjai, valamint az állami oktatási intézmények és tanügyigazgatási szervek delegáltjai kerültek be (pl. tanfelügyelök, tankerületi igazgatók és egyetemi oktatók). Vagyis míg az I. Napóleon nevéhez köthető testület összeté-

4 Részlet a Schwendtner Tibor által 2021. október 29-én küldött elektronikus levélből. 
tele tekintetében a felülről történő kinevezés játszott meghatározó szerepet, közel fél évszázad múlva hibridjellegü, a delegálás és a kinevezés elvét vegyítő rendszer jött létre.

Ez a hibrid jelleg a kiváló tudós és művelődéspolitikus Schvarcz Gyula által kidolgozott, a felállítandó Országos Közoktatási Tanács fö vonásait rendkívül részletesen vázoló, kiegyezés előtt született tervezetben is tetten érhető. A terv egyes részleteit kilenc évvel ezelőtt publikált tanulmányomból ismerhette meg az oktatástörténet iránt érdeklődő mai olvasó (Bajomi 2012: 180). A tervezetet az oktatás reformjáról átfogó módon gondolkodó tudós 1866-ban publikálta a tulajdonában lévő Új korszak címü, már címében is egyfajta politikai rendszerváltást előrevetítő hetilapban. E javaslat szerint az új grémium tagjai „a magyar közoktatási miniszter által neveztetnek ki”. Ugyanakkor Schvarcz szerint a testület összetételét nem kizárólag az oktatási tárca vezetője határozta volna meg saját preferenciái szerint. Mint írta, a grémium tagjai „azon kétszáz jelölt közül neveztetnek ki, kiket a magyar tudományos akadémia fog mint jelölteket felterjeszteni, tekintettel a hazai köztudományosság körében szerzett érdemeikre, a közoktatásügy körül szerzett tapasztalatokra és a vallásfelkezetek és a nemzetiségek kellő képviseletére" (121 §) (Bajomi 2012: 180). Ezen túlmenően az európai oktatási rendszerekről átfogó képpel rendelkező tudós azt is javasolta, hogy a testület tagjai szakosztályokba szerveződjenek, méghozzá oly módon, hogy a testületben az oktatási rendszer különböző fokozatai és speciális intézményei is képviselve legyenek.

A fentieket összefoglalva azt mondhatjuk, hogy a Schvarcz-féle tervezetben a tagok miniszter általi, azaz felülről való kiválasztásának elve mellett a képviseleti elv is megjelent, mégpedig többféle értelemben is, hisz elvben a testületnek az oktatás intézményrendszerének differenciáltságát, továbbá vallási és nemzetiségi tekintetben mutatkozó sokféleségét is meg kellett volna jelenítenie.

E sokféleséggel kapcsolatban feltétlenül említést érdemel, hogy az 1860-as években megalakult tanár- és tanítóegyesületek egyik legerősebbike, az Országos Középtanodai Tanáregylet nevében szólók egy 1869-ben Pauler Tivadar vallás- és közoktatásügyi miniszternek címzett emlékiratukban arról írtak, hogy az igen differenciált oktatási rendszerben jelentkező problémák együttes és koherens kezelését segíthetné elő az Országos Közoktatási Tanács létrehozása: „Hogy a tanügyi intézkedések valóban üdvösek lehessenek, s meddő experimentálásokkal a drága idő el ne pazaroltassék; a tanári egylet elkerülhetetlenül szükségesnek tartja egy valódi szakférfiakból, s minden rendü tanintézetek jeleseiből összeállított tanügyi tanács szervezését, mely mindenekelőtt a tanintézeteknek egybevágó gépezetéről, az egyes intézeteknek célja- és feladatáról készítsen általános tervezetet. A részletek kidolgozása ezután a munka könnyebbik része leend." (Az Országos 1869: 21-22.)

2012-es tanulmányomban az Országos Közoktatási Tanács megalakítása körüli viták kapcsán György Aladár pedagógiai szakírónak és müvelödéstörténésznek egy 1871. november 8-i cikke alapján csupán arról írtam - mintegy a létrehozandó grémiumról való gondolkodás egyfajta társadalmi diffúzióját érzékeltetendő - , hogy az Országos Középtanodai Egylet 1869-es javaslatát követően 1870. április 20-án egy újság lapjain „egy gyakorlati tanférfiú” is állást foglalt a testület megalakulása mellett, illetve hogy ugyanazon év február hónapjában a Szabolcs megyei iskolatanács a szóban forgó országos testület megalakítása ügyében „a törvényhozáshoz és a szakminisztériumhoz a megye útján indítványt terjesztett elö". (Bajomi 2012: 183.) Kilenc évvel ezelőtti írá- 
somban még nem szolgáltam bővebb információkkal e kezdeményezésekről, de részben az internetes sajtókeresésnek köszönhetően mára már megváltozott a helyzet.

Míg egy évtizede még kézzel jegyzeteltem, vagy fénymásolatokat rendeltem a megtalált fontosabb írásokról, a napokban könnyedén sikerült letöltenem a Pesti Napló hasábjain 1870 áprilisában közölt - érdekes módon az oktatásirányítás jelenlegi jellemzőiből következően ma is aktuálisnak mondható - kéthasábos írást, amelyben a szerző azért javasolta egy közoktatási tanács felállítását, hogy az állami kézben lévő iskolák tanerői is hasonló autonómiát élvezhessenek, mint amilyent az egyházi iskolákban tanítók élvezhetnek ténylegesen - vagy legalábbis elvben - a saját felekezetük szintjén: „A felekezeteknek megadja a törvény a jogot: tankönyveiket s tanrend és módszerüket meghatározni. Nem az egyes hitfelekezeti iskolák elkülönzött egyes hatóságai bírnak azon jogokkal, hanem a hitfelekezet összességben. A protestánsok e jogokat, a dolog természete szerint egyházkerületeik választott főhatóságai által gyakorolták. A természete szerint ugyanígy fogják azt más hitfelekezetek is gyakorolni, mihelyt önkormányzatukban szervezkedniök sikerül. Így gyakorolták eddig is, azon különbséggel, hogy e jogokat nem a hitfelekezet maga, önkormányzati alapon, hanem az uralmat tartó egyházfőségek gyakorolták, inkább egyházhatalmi érdek s irányban, sem mint a felvilágosodás szolgálatában. Közös iskoláinkra nézve megvan immár a törvényben magva az iskolai főhatóság kifejlesztésének." A dualizmus kezdetei után mind jobban kiépülő állami tanügyi bürokrácia ellenőrzésére, befolyásolására, illetve az állami, községi tanintézményekben dolgozók autonómiájának megteremtésére irányuló fenti gondolatok megfogalmazása után a „tanférfiú” egy többszintes, az önkormányzatiság logikájára épülö testületi modellt vázolt fel, miközben tartózkodott attól, hogy egy testületi rendszerben müködő (dikaszteriális) kormányzati modell mellett tegye le a garast, illetve hogy egy folyton ülésező grémium létrehozására tegyen javaslatot: „Ott vannak első vonalban helyi iskolaszékeink, másodfokúlag a szélesebb áttekintéssel, s magasb látkörrel bíró iskola tanácsaink: mind önkormányzati alapon választott testületben az állam felügyeleti jogát képviselő tanfelügyelővel. E hatóságokból mily könnyű egy országos közoktatási tanács megalakítása: mely a tanterv s tanrend és módszer felett időről-időre határozzon. Nem szeretnénk ez országos közoktatási tanácsot, parlamenti kormányrendszer mellett, állandó dicasterialis közeggé tenni. A közoktatási miniszter alárendelt orgánumaival még igen soká szükséges leend a törvényeknek a közoktatás érdekében [való - B. I.] végrehajtására. Az országos közoktatási tanácsot, mint feladatának szakszerü megoldására hivatott testületet, válaszztva az iskolatanácsok által saját kebelükből, s mindenik iskolatanács köréből 1-1 taggal, melyhez a közoktatási miniszter $1 / 2$ arányban jelölne tagokat a tanfelügyelők közül - úgy óhajtanók időnként öszszehívatni, mint az enquete-ket ${ }^{5}$ [ankétokat - B. I.] szokás, mikor szükség van reájuk." (Országos 1870.)

Az Arcanum Digitális Adattárának köszönhetőn a Szabolcs megyei iskolatanács már korábban említett, 1870. februári előterjesztése kapcsán is szolgálhatok új információkkal. Az előző bekezdésekben aránylag részletesen bemutatott javaslat ugyanis írásra ihlette a Pesti Napló egyik nyíregyházi olvasóját, aki május 4-én kelt levelében a következőket tudatta: „Nagy érdekkel olvastam [az ...] »országos közok-

A többjelentésű, többek között a mai hivatalos „közmeghallgatásokat” is jelölő francia „enquête” fónév utóbb az „ankét” szó formájában honosodott meg a magyar nyelvben. 
tatási tanács« felállítására vonatkozó közlést. Érdekeltségem annál nagyobb volt, mivel ugyan e tárggyal a szabolcsmegyei tankerületi iskolai tanács utolsó gyülésében foglalkozott. Tanfelügyelő tokaji Nagy Lajos úr, ki azon helyes alkotmányos elvből indul ki, hogy a törvényeknek a gyakorlat által tapasztalt hiányait minden, arra magát hivatottnak érző jogosult felderíteni, tette meg az indítványt, mely közhelyesléssel találkozott és mely szerint az iskola tanács a közoktatásügyi minisztériumhoz feliratot intézett, hogy a népoktatási törvényt törvényhozás útján akkép módosíttassa, hogy egy országos közoktatási tanács e törvény keretében méltó helyet és szerepet találjon." (r. l. 1870.)

Miként az olvasói levélből valószínüsíthető, elsősorban egy helyi notabilitás, a Szabolcs megyei iskolatanács élén álló tanfelügyelő személyéhez köthető az országos közoktatási tanács felállítását szorgalmazó, eddigi ismereteink szerint elsőnek tekinthető helyi szinten megfogalmazott indítvány. ${ }^{6}$ Minthogy ma nemigen ismert, hogy a dualizmus korai éveiben mit kellett érteni a megyei iskolatanács fogalmán, hadd álljon itt magyarázatul, hogy ezek delegálás útján létrejött testületek voltak, melyek tagjai egyrészt a megyei bizottmányok (mai szóval közgyúlések) és a szabad királyi városok képviselőtestületei által delegált személyekből, másrészt a vármegye területén müködő vallásfelekezetek egy-egy küldöttjéből, harmadrészt pedig a megye területén létesült nyilvános népiskolák tanerői által jelölt négy tanítóból álltak. E testületek egyik legfontosabb feladata az volt, hogy tanácskozzanak ,a tankerület tanügyi viszonyairól, különösen arról, hogy a helyi s vidékbeli érdekeknek megfelelőleg, hol minő tanintézet felállítása szükséges, s mennyiben kellene azt [...] állami erővel létesíteni” (Utasitás 1869: 706).

És minthogy a Szabolcs megyei és Hajdú kerületi iskolatanácsot vezető Tokaji Nagy Lajos személye sem közismert, érdemes megemlíteni erről a Nyírségből utóbb Budapestre költözött közjegyzőről, hogy számos egyéb, a közjót szolgáló kezdeményezése mellett nevéhez füződik annak a Szabolcs megyéből elindult gyüjtésnek a meghirdetése is, mely arra irányult, hogy az ország fővárosában méltó székház épülhessen a Magyar Tudományos Akadémia számára. (És ezzel vissza is kanyarodtam cikkem elejéhez, ahol megemlítettem, milyen szívesen kutakodtam egykoron régi újságokat lapozgatva a Duna-parti neoreneszánsz MTA-székházban müködő könyvtárban.) Egyébként a tanfelügyelö által megfogalmazott indítvány indoklása is figyelmet érdemel, hisz e rövid szövegrészben egy olyasfajta demokratikus meggyőződés fogalmazódott meg, mely szerint mindenkinek joga van arra, hogy gyakorlati tapasztalatai alapján bírálatot fogalmazzon meg a törvényekkel kapcsolatban, miként arra is, hogy ezeket jobbító javaslatokat tegyen. Tóth Sándor helytörténész alábbi sorait olvasva nem lepődhetünk meg azon, hogy ilyesfajta meggyőződés jegyében lépett fel a megyei tanfelügyelőként is müködő közjegyző: „Szabolcs megyében Tokaji Nagy Lajos volt a kezdeményezője az első demokratikus közösségi formáció megalakulásának. 1867. december közepén, a Nyír c. újság hasábjain jelent meg a felhívása demokrata körök alakulására. Ebben a felhívásban fejti ki a demokrácia szükségességét, az egyesülések jelentőségét az alkotmányos elvek megvalósításában az elmaradott társadalom felzárkóztatását a demokrácia eszméjének elterjesztése által. A demokrácia elterjesztését, megvalósítását tekintet-

6 Fontos lenne elemezni, hogy a Szabolcs megyei iskolatanács keretei között megfogalmazott javaslat megszületésében milyen szerepet játszottak önkormányzatisággal kapcsolatos hagyományok, beállítódások, amelyeknek a dualizmus korának kezdetén meghatározó szerepük volt a megyei közigazgatás területén. E közigazgatási hagyomány részletesebb bemutatását lásd Nagy Endre tanulmányában (Nagy 1986). 
te az egyesülések feladatának. Ezekben az egyesületekben a törvény előtti egyenlőség eszméje szellemében képzelte el a társadalom tagjainak felkészítését a demokratikus elvek gyakorlására." (Tóth 2018: 15.)

Nem kizárt, hogy levéltári kutatások révén a jövőben előkerül majd a Tokaji Nagy Lajos nevéhez köthető, 1870. februári javaslat szövege, ám egy, a napokban végzett elektronikus sajtóforrás-keresésemnek köszönhetően a fentebb bemutatottakon túl immár néhány további támpont is felbukkant a szóban fogó javaslattal kapcsolatban. 2012-es írásomban már jeleztem, hogy 1871 májusától egyfajta társadalmi, illetve sajtóvita bontakozott ki azzal a „szabálytervezettel” kapcsolatban, amelyet a vallás- és közoktatásügyi miniszter tett közzé fövárosi lapokban 1870 májusában, és amely a létrehozandó közoktatási tanács jellemzőit mutatta be. Mostani kutakodásaim közben kiderült, hogy az Ellenör címü újság egyik számának címoldalára került 1871 nyarán egy közel háromhasábnyi terjedelmű, Nagykállóban kelt szöveg, amelyben „a szabolcsmegyei tankerület küldöttsége" részletes bírálatban részesítette a leendő Országos Közoktatási Tanács müködésmódját leíró „szabálytervezetet”, majd a szöveg második felében egy terjedelmes törvénytervezetet adtak közre, amely ugyanennek a testületnek a kívánatos jellemzőit mutatta be. Bár a szöveg 1871-ben íródott, vélhetően mégis következtetni lehet belőle a Szabolcs megyei iskolatanács égisze alatt közel másfél évvel korábban elfogadott javaslatra. Az 1871 nyarán írt cikkben ugyanis ez áll: „E küldöttség, vezérfonalul vevén, a Szabolcs megyei tankerület iskolatanácsának 1870 febr. 14-én kelt határozatát, melyben az országos közoktatási tanács alkotása iránt első indítványozóul lépett fel; s javaslata az 1868. XXXVIII. 130. \$. 4-ik pontja értelmében a megye által is elfogadtatván, ez úton a képviselőházhoz is felterjesztetett: a miniszteri tervezetet elfogadhatónak nem véleményezi." (Az országos 1871a.) Elutasító véleményét számos érvvel indokolta a Szabolcs megyei iskolatanács küldöttsége, melyek között különösen fontosak voltak azok, amely a testület „felülről szerveződő” jellégét kifogásolták: „mert a tervezet szerint az országos közoktatási tanács, sem független testület, sem az önkormányzat elveinek megfelelően szervezve nem lenne, sem az ország tanügyi szükségei s igényeinek - megbízható közegéül nem tekintethetnek [...]. Az indokolás a következő: 1. hogy a közoktatási tanács független testület, szervezeténél fogva nem lenne: tanúsítja az 1. 7. 11. es 12 -ik $\S$-a, melyek szerint e tanács a minisztérium »oldala mellett« lenne, az alelnök, a 26. beltag felét, a határozatlan számú kültagokat mind, s a tanácsjegyzőt a miniszter nevezné ki, s ráadásul - még határozati joggal tagja lenne a tanácsnak a minisztérium valamennyi előadó tanácsosa. Így a tervezet a miniszter által kinevezett s beküldött tagokkal már túlnyomó többséget szerez a miniszternek; mely többségét a 13. választott beltag ellenében, a kinevezett kültagokkal." (Az országos 1871a.)

A fentiekhez képest némi kitérőt téve érdemes visszatérni a korábban már idézett nyíregyházi olvasói levél szerzőjének szövegéhez, mivel a levél második bekezdése azt jelzi, hogy a közélet iránt érdeklődők számára ismert - és vélhetően a politikaformálásra törekvők számára még inkább fontos - adottság lehetett az 1870-es évek elején 1868 óta folyamatosan müködtetett Országos Közegészségi Tanács létezése. E javaslattevő joggal is felruházott testület fö funkciója az volt, hogy a kormányzat számára hozzáférhetővé tegye az egészségügyben, ebben az egyre növekvő fontosságú társadalmi alrendszerben koncentrálódó speciális szaktudásokat és tapasztalatokat. Ez utóbbiak jelentőségére és a kormányzati munkában történő hasznosításának fontosságára mindenekelőtt a visszatérően jelentkező járványok és különféle népbetegségek jelentette prob- 
lémák hívták fel a figyelmet. (Lásd ezzel kapcsolatban Kiss László disszetációját [Kiss 2015].) A szóban forgó egészségügyi testület létrehozását szorgalmazó „Emlékirat” szerzői, akik a kor orvoslásának jeles szakemberei voltak (Balassa János, Jendrássik Jenő, Korányi Frigyes és Markusovszky Lajos) így fogalmazták meg a felállítandó Országos Közegészségi Tanács feladatait: „Szükséges, hogy a kormány mely [...] oly egyénekből álló testülettel rendelkezhessék, mely megkívánható tudományok és tapasztalatok színvonalán állván, képes legyen a kormányt feladatában tanácsával segíteni, mely tehát nemcsak egyes előforduló esetekben adjon szakértő véleményt, hanem a [...] törvényjavaslatokat is elkészítse, s ezek alapján a szükséges utasításokat kidolgozza, vagy felülvéleményezze általában azon legyen, hogy mindaz, amit a tudomány a fenn nevezett célokra nézve hasznosat felfedez, a közjó érdekében hasznosíttassék." (Balassa és mtsai 1868: 192.)

$\mathrm{A} z$ imént mondottak fényében különösen érdekesek a már idézett nyíregyházi olvasói levél szerzőjének alábbi szavai, melyben a szerző az Országos Közoktatási Tanács létrehozásával kapcsolatos ellenérvek kivédése érdekében hozakodott elő az Országos Közegészségi Tanács példájával: „Azon netaláni ellenvetésre, hogy egy testület müködése nem fér össze a miniszter személyes felelősségével, bátorkodom a belügyminisztérium kebelében létező országos közegészségügyi tanácsra hivatkozni. Valamint a közegészségügyi tanácsnak oly kérdésekben, melyeknek eldöntéséhez szakképzettség kívántatik, a minisztert informálja, ugyanazon hivatás jutna a közoktatási tanácsnak a közoktatásügyi miniszter ellenében. Szakkérdések pedig mindig inkább testületek által intézendők el, melyek inkább képesek azon garanciát nyújtani, hogy a kérdéses ügyek nem fognak egyéni egyoldalú fölfogás szerint elintéztetni. A végrehajtás és az azérti felelösség mindig egy személyben marad összpontosulva, és a személyes felelősséget nem sérti azon körülmény, hogy bizonyos, a törvény által szabatosan megállapítandó szakkérdésekben a miniszter elébb egy szakértőkből álló testület tanácsát kéri ki." (r. l. 1870.)

A tanulmányomban idézett 1870 körüli publikációk jól érzékeltetik, hogy az Országos Közoktatási Tanács létrejöttét megelőzően a korábbi írásomban jelzettnél is markánsabban voltak jelen azok a törekvések, amelyek egy felülről szerveződő grémium helyett egy főként delegáláson alapuló, az önkormányzatiság elvét érvényre juttató szerveződésmódot tartottak volna kívánatosnak. Az Országos Közoktatási Tanács 1871 decemberében Ferenc József által aláírt szabályzatában köztes megoldás jelent megः egyszerre jutott érvényre a kinevezéses és a képviseleti logika: „11. $\S$. Az alelnököt, mindegyik szakosztály beltagjainak felét, s igy összesen tizenöt beltagot, figyelemmel arra, hogy a közoktatás egyik szaka se maradjon szakismerő képviselő nélkül, továbbá valamennyi kültagot, és a tanácsjegyzőt a tanügy iránt részvétet tanúsított bármi rangú és rendű férfiak köréből három évre a magyar királyi közoktatási miniszter nevezi ki; a többi tizenöt beltag közül pedig három évre az egyetemi tanárok köréből hármat választ a pesti magyar kir. tudományegyetem tanácsa a tudomány-egyetemi szakosztály, - továbbá szintén három évre saját kebeléből kettőt a müegyetem tanácsa, a müszaki szakosztály, - ötöt az országos középtanodai tanáregylet [...] és végre hármat a budapesti népiskola s tanitó-képezdei tanítók gyülekezete az illető tanfelügyelő elnöklete alatt a népiskolai szakosztály számára." (Szabályzat 1871.) Ugyanakkor a grémium 1875-ös átszervezése után egyértelmüen a felülről lefele szerveződés elve jutott érvényre, azaz a tagok miniszter általi kiválasztása, kijelölése vált gyakorlattá. 
Két évtizeddel később, azt követően, hogy a vallás- és közoktatásügyi miniszter pozícióját rövid ideig betöltő Eötvös Loránd 1894 decemberében felfüggesztette a testület müködését, utóda, Wlassics Gyula újra lehetővé kívánta tenni az OKT főként a tantervfejlesztés és a tankönyvek ellenőrzése, elfogadása tekintetében kormányzati szempontból többnyire hatékonynak bizonyult testület munkálkodását (Vass 1996). $\mathrm{A} z$ újjászervezési folyamat keretében a kultuszminisztériumban tartott tanácskozáson a meghívottak körében egyaránt voltak olyanok, akik a delegálás elve, illetve akik a minisztérium általi kiválasztás elve mellett szóltak. Ha nincs is mód az 1895-ben megfogalmazott vélemények teljes körű bemutatására, hadd álljon itt több markáns álláspont! Heinrich Gusztáv irodalomtörténész azt javasolta, hogyः „a tanács csak orgánum legyen s ne adminisztráljon. A tagok választását egyesületek vagy körök útján céltalannak tartja”. Fenyvessy Ferenc ügyvéd és politikus, a képviselőház közoktatási bizottságának jegyzője köztes véleményt fogalmazott meg: „A tagok száma, részben kinevezés, részben a tanári testületekből való választás útján szaporítandó." Szintén köztes álláspontot képviselt a tanácskozásra meghívott „alapító atya”, amikor a három évtizeddel korábban az Új kezdet hasábjain megfogalmazott elgondolásához hasonló megoldást javasolt: „Dr. Schvarcz Gyula a tanácsot szintén véleményadó testületnek óhajtja, úgy azonban, hogy a tanács létesítésére nézve a képviseltetés eszméjének bevonását is szeretné. Azt, hogy a tanács tagjait egyes karok vagy testületek válasszák be, nem helyesli, de azt igenis, hogy az egyes körök, kapcsolatok, testületek stb. a kandidáció [a javaslattevés - B. I.] jogával bírjanak." Lánczy Gyula történészprofesszor így érvelt a delegálás mellett: „külföldi példák nyomán úgy vélekedik, hogy a tanács akként legyen szervezve, hogy véleményének súlya is legyen, ami leginkább akkor lesz elérhető, ha a tanács a képviseltetési elv alapján mondana véleményt." (A közoktatási 1895.)

Majd egy évszázad múlva, az 1988-1990 közötti politikai rendszerváltást követő években lehetővé vált az 1945 és 1948 között működtetett, majd négy évtizedig „szüneteltetett" Országos Köznevelési Tanács újjászervezése. Ekkor az oktatási tárca vezetője, Andrásfalvy Bertalan a felülről lefele építkezés elve jegyében egy, az egykori titkos királyi tanácsokra emlékeztető 15 fős Országos Közoktatási Tanács felállítása mellett döntött (Mann 1992). A később megfogalmazott bírálatok hatására 1993-ban lehetővé vált, hogy egy delegálás alapján szerveződő testület jöjjön létre. Ugyanakkor a korabeli oktatási kormányzat úgy irányította a dolgot, hogy két egymástól függetlenül mủködő konzultatív testület jöjjön létre. Egyfelől a hivatalosság által szakmaiként definiált érdekcsoportok delegáltjainak (pl. a tanárképző intézmények, az MTA és a pedagógiai egyesületek képviselőinek) teret adó Országos Köznevelési Tanács jöhetett létre, másfelöl a laikusként kezelt érdekcsoportok (pedagógusszakszervezetek, iskolafenntartó önkormányzatok, szülői és diákszervezetek, iskolafenntartó egyházak) képviselőit magában foglaló új testület, a Közoktatás-politikai Tanács. E kettőség jegyében ettől kezdve mindkét grémium külön, azaz egymással nem érintkezve alkothatott véleményt a közoktatással kapcsolatos kérdésekről és a készülő jogszabályokról. (Bajomi 2010.)

További fontos újabb keletű fejleményeként értékelhető, hogy 2010 után, a fokozatosan egyre diktatórikusabbá váló politikai rendszer keretei között a Köznevelési Törvény 2011-es elfogadásával megszűnt az 1993-ban felállított Közoktatás-politikai Tanács, miként az is, hogy az elmúlt években semmiféle értékelhető nyilvános tevékenység nem köthető az elvben továbbra is létező Országos Köznevelési Tanácshoz (BajomiCsákó 2017). 


\section{IRODALOM}

A közoktatási (1895) A közoktatási tanács reformja. Pesti Napló, 1895. május 27.

A közoktatásügyi (1870) A közoktatási tanácsról. Pesti Napló, május 4. Melléklet.

Az Országos (1869) Az Országos Középtanodai Tanáregylet emlékirata a Vallás- és Közokt.

M. Kir. Ministerium által kiadott gymnasiumi és lyceumi tanszervezeti javaslatok ügyében. Budán, 1869. https://mandadb.hu/tetel/581271/Az_Orszagos_Kozeptanodai_ Tanaregylet_emlekirata_a_Vallas_es_Kozokt_M_Kir_Ministerium_altal_kiadott_ gymnasiumi_es_lyceumi_tanszervezeti_javaslatok_ugyeben [Letöltve: 2021. 12. 17.]

Az országos (1871a) Az országos közoktatási tanácsról. Ellenőr, július 21.

Az országos (1871b) Az országos közoktatási tanács szabályzatát [...]. Ellenôr, december 16.

Вајомг I. (2006) Az Országos Köznevelési Tanács visszaállítását szorgalmazó '56-os javaslat. Educatio, Vol. 15. No. 3. pp. 492-510.

Вајомі I. (2010) Tanügyitanács-barkácsolás az Antall-kormány idején. In: A cselekvő értelmiségi - Tanulmányok Huszár Tibor 80. születésnapjára. Budapest, Argumentum - ELTE TáTK. pp. 28-38.

Вајомі I. (2011) A tanügyi tanácsokkal kapcsolatos 1969 és 1989 közötti reprezentációk és javaslatok. In: Kulcskérdések a társadalomtudományban, 2011-2012. Etikai dilemmák. Az ELTE Társadalomtudományi Karának konferenciája, 2011. május 26-27. pp. 135150. https://tatk.elte.hu/dstore/document/100/kulcskerdesek_2011-2012_e-book.pdf [Letöltve: 2021. 12. 16.]

Вајомг I. (2012) Az első tanügyi tanács körüli viták. Educatio, Vol. 21. No. 2. pp. 179-189.

Вајомі I. \& CsÁкó M. (2017) Fórumok és tiltakozómozgalmak a közoktatásban. Educatio, Vol. 26. No. 4. pp. 528-539.

Balassa J., Jendrássik J., Korányi F. \& Markusovszky L. (1868) Emlékirat a közegészségi és orvosi ügy rendezése tárgyában. Orvosi Hetilap, 1868. március 15. pp. 189-197.

Bonaparte, N. \& Maret, H.-B. (1808) Décret impérial No 3179 portant sur organisaton de l’Université (Az Egyetem szervezetéről szóló 3179-es számú császári rendelet). (1808. március 17.) Bulletin des lois, No 185. pp. 145-171. https://www.persee.fr/doc/ inrp_0000-0000_2007_ant_22_1_8484 [Letöltve: 2021.12.16.]

Comité (é.n.) Comité d'instruction publique (Közoktatási Tanács). https://fr.wikipedia.org/ wiki/Comit\%C3\%A9_d\%27instruction_publique_(France) [Letöltve: 2021.12.16.]

Conseil (é. n.) Conseil supérieur de l'instruction publique (Közoktatási Fötanács). Dictionnaire Ferdinand Buisson. http://www.inrp.fr/edition-electronique/lodel/dictionnaireferdinand-buisson/document.php?id=2447 [Letöltve: 2021. 12. 16.]

Honvátr M. (1875) Az Országos Közoktatási Tanács átalakulása. Magyar Tanügy, 1875. pp. 455-467.

KIss L. (2015) A magyar közegészségügy fejlödése a közegészségügyi gondolkodás kialakulásától az állami közegészségügyi rendszer kiépitéséig. ELTE TÁTK, doktori disszertáció.

Mann M. (1992) Az Országos Közoktatási Tanács kezdetei. Új Pedagógiai Szemle, Vol. 42. No. 3. pp. 88-92.

Nagy E. (1986) Társadalomfejlődés és közigazgatási reformok. Világosság, Vol. 27. Nos 8-9. pp. 506-513.

r. 1. (1870) A közoktatásügyi tanácsról. Pesti Hirlap. május 7. Melléklet.

Országos (1870) Országos közoktatási tanácsról. Egy gyakorlati tanférfiú indítványa. Pesti Napló, április 20.

Sarkadi L. (1988) Beszélgetés Zibolen Endrével. Budapest, Educatio Kiadó. 
Schwendtner T. (2017) Filozófusok és hivatalnokok - megjegyzések a Berlini Egyetem alapításához. Magyar Pedagógia, Vol. 117. No. 4. pp. 381-397.

Schwendtner T. (2018) Humboldt közoktatási reformjai emberképének fényében. In: Sárkány Péter \& Schwendtner Tibor (eds) A filozófia lebetséges szerepei a neveléstudományban. Eger, EKE Líceum Kiadó. pp. 63-83.

Szabályzat (1871) Szabályzat az Országos Közoktatási Tanács számára. Magyar Újság, 1871. december 17 .

Tótн S. (2018) Tokaji Nagy Lajos közjótevő szabolcsi évtizedei. (Kézirat.)

Utasítás (1869) Utasítás a tankerületi iskolatanácsok számára. 1869. május 21. Báró Eötvös József. In: Magyarországi rendeletek tára, 1869. Harmadik folyam, Pest, Ráth Mór kiadása.

VARGA L. (1960) Részletek a magyar közegészségügy történetéből, különös tekintettel az Országos Közegészségi Tanács megszervezésére és első negyedszázados működésére. Kézirat. Bp. 1960. (A Budapesti Orvostörténeti Könyvtár tulajdona.)

VAss V. (1996) Az Országos Közoktatási Tanács tantervi munkálatai a XIX. században. Magyar Pedagógia, No. 3. pp. 231-250.

A cikk a Creative Commons Attribution 4.0 International License (https://creativecommons.org/licenses/ by/4.0/) feltételei szerint publikált Open Access közlemény, melynek szellemében a cikk bármilyen médiumban szabadon felhasználható, megosztható és újraközölhető, feltéve, hogy az eredeti szerző és a közlés helye, illetve a CC License linkje és az esetlegesen végrehajtott módosítások feltüntetésre kerülnek. (SID_1) 